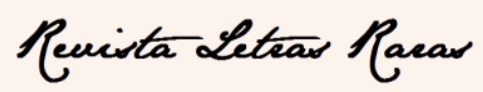

ISSN: 2317-2347 - v. 8, n. 3 (2019)

\title{
Presente na luta!
}

Ariana da Rosa Silva*

Recebido em 09 jul. 2019. Aprovado em 18 ago. 2019.

Sujeito

Errante

Desejante

Falante

Se revolta

Se movimenta

E luta!

A linguagem

A língua

A letra

Se revolta

Se movimenta

E luta!

O desejo

A angústia

O desespero

Se revolta

Se movimenta

E luta!

\footnotetext{
* Mestra e Doutoranda em Estudos de Linguagem na Universidade Federal Fluminense (UFF). E-mail: arianarosa86@gmail.com
} 


\section{Reuista Leteas Paear}

ISSN: 2317-2347 - v. 8, n. 3 (2019)

A memória

A história

Se escreve

Se reescreve

Se revolta

Se movimenta

E luta!

A resistência

Do sujeito

Da língua

Do desejo

Da história

Está Presente

Na luta! 